\title{
Financial Inclusion and Human Capital in Developing Asia: The Australian Connection
}

\begin{abstract}
The Australian government as part of its aid programme allocates large funds to improve financial inclusion in the developing countries. This, however, does not take into account low educational levels in these countries. The existing literature on financial inclusion also treats the issue of financial inclusion as mainly supply centric and does not take cognizance of the fact that poor human development and high illiteracy levels in developing economies may prevent a large section of the population from benefitting from financial inclusion efforts due to low awareness and comprehension of the financial services. In this study by using a detailed three stage methodological approach we examine the relationship between financial development and human capital in 21 countries of developing Asia. The results of our study show that a significant negative relationship exists between financial development proxied by M2/GDP and pupil-teacher ratio and strong positive relationship exists between physical access to banks and expected years of schooling. Further, our financial development and educational development indices also show no clear pattern in the selected countries financial and educational development.
\end{abstract}

\section{Introduction}

In recent years financial inclusion has become an important policy goal in developing countries. Even though its definition is not clear and varies from 'banking the unbanked' to 'branchless banking', yet its importance stands tall as it is increasingly viewed as a tool of poverty alleviation, achievement of Millennium Development Goals, enables poor to be risk averse, and also to invest in their health and education. Financial inclusion has become all the more important as studies have increasingly shown that poor people, despite their low incomes and small amount of funds available at hand, actively manage and diversify their portfolios into different financial products even though outside the formal financial system. ${ }^{2}$

A growing literature focuses on the measurement and concept of financial inclusion. This literature, however, treats the issue of financial inclusion as mainly supply centric and assumes that the supply of financial services alone will lead to an inclusive financial development. It does not take cognizance of the fact that poor human development and high illiteracy levels in developing economies may prevent a large section of the population from benefitting from financial inclusion efforts due to poor awareness and comprehension of financial services. 
The Australian Government, as part of its support to the developing countries in the AsiaPacific region in their fight against poverty aims to increase financial services to the poor. In its financial inclusion strategy for 2010-2015, a number of policy outcomes and guiding principles have been identified by the government to assist and work with the stakeholders to increase financial inclusion. ${ }^{3}$ The relationship between existing human capital in these countries and financial inclusion, however, remains unexamined. It is not known whether existing human capital has any influence on the efforts to increase financial inclusion and whether higher human capital will lead to better utilisation of financial services.

In this study, in a cross-country analysis, using data from a variety of sources such as IMF, World Bank and UNDP for the years 2000-2010 we examine the relationship between human capital and financial inclusion in developing Asia. A large number of studies exist on returns to education and its contribution to economic growth. Education has also been related to superior development outcomes such as health, nutrition, fertility, the impact of mothers' education on children's health and schooling; and the adoption of technology particularly in the agricultural sector. ${ }^{4}$ The contribution of finance to economic growth has also been firmly established in the literature. ${ }^{5}$ King and Levine (1993 a \& b) and Gregorio and Guidotti $(1995)^{6}$ showed that the higher levels of financial development are positively associated with faster rates of economic growth. Levine (1997) concluded that, 'theoretical reasoning and empirical evidence suggests a positive, first-order relationship between financial development and economic growth'. ${ }^{7}$ The inter-relationship between financial development and education, however, has been an under-researched and little understood area.

Our study follows a detailed three-stage methodology. In the first stage, following the methodology used by UNDP in the construction of Human Development Index, using 
multidimensional indicators we build financial development index and education development index. This enables us to have quick look at the level of financial and educational development in our sample countries. Further, we conduct Principal Components Analysis (PCA) to shortlist select variables and in the final stage using Ordinary Least Square (OLS) method perform regressions to examine the relationship between financial development and human capital. Using various diagnostic tests we also check the robustness of our regressions.

The results of our study show that there is no clear pattern and the countries rank differently in educational development and financial development. In particular, we observe that the countries which ranked high in educational development did not rank high in financial development. Further, we find a strong positive relationship between physical access to banks and expected years of schooling and mean years of schooling. We also note significantly negative relationship between our financial development proxy indicator - M2/GDP ratio and the indicator showing quality of education, pupil-teacher ratio.

Porteous $(2009)^{8}$ and Hannig and Jansen $(2010)^{9}$ pointed out the need for more research to examine how appropriate and favourable policies can play a positive role in improving financial inclusion. In particular, Hannig and Jansen also hinted at the need for increased consumer protection and financial literacy in view of poor education among unbanked customers. Our study in this spirit contributes to the existing literature and deepens our understanding of the complexities of financial inclusion. It furthers the debate on the choice of policies by targeting human capital as an influencing factor on financial inclusion.

The plan of the study is as follows. Section 2 traces the extent of financial inclusion in developing Asian countries and highlights Australia's support in improving the financial 
sector in these countries. Section 3 discusses briefly the educational attainment of these countries. Section 4 reviews the theoretical and empirical relationship between finance and human capital. Next we discuss the methodology followed in the study and our data and model specification. Section 6 presents the results and the final section concludes the study.

In our study, developing Asia refers to 27 countries as classified by the IMF. ${ }^{10}$ For our purpose we, however, include only 21 countries in our analysis and exclude others due to data limitations. These are a diversified group of countries and their average per capita income was $\$ 2145$ in 2008. The standard deviation is $\$ 1648.56$ and the coefficient of variation is high at 76.8 per cent.

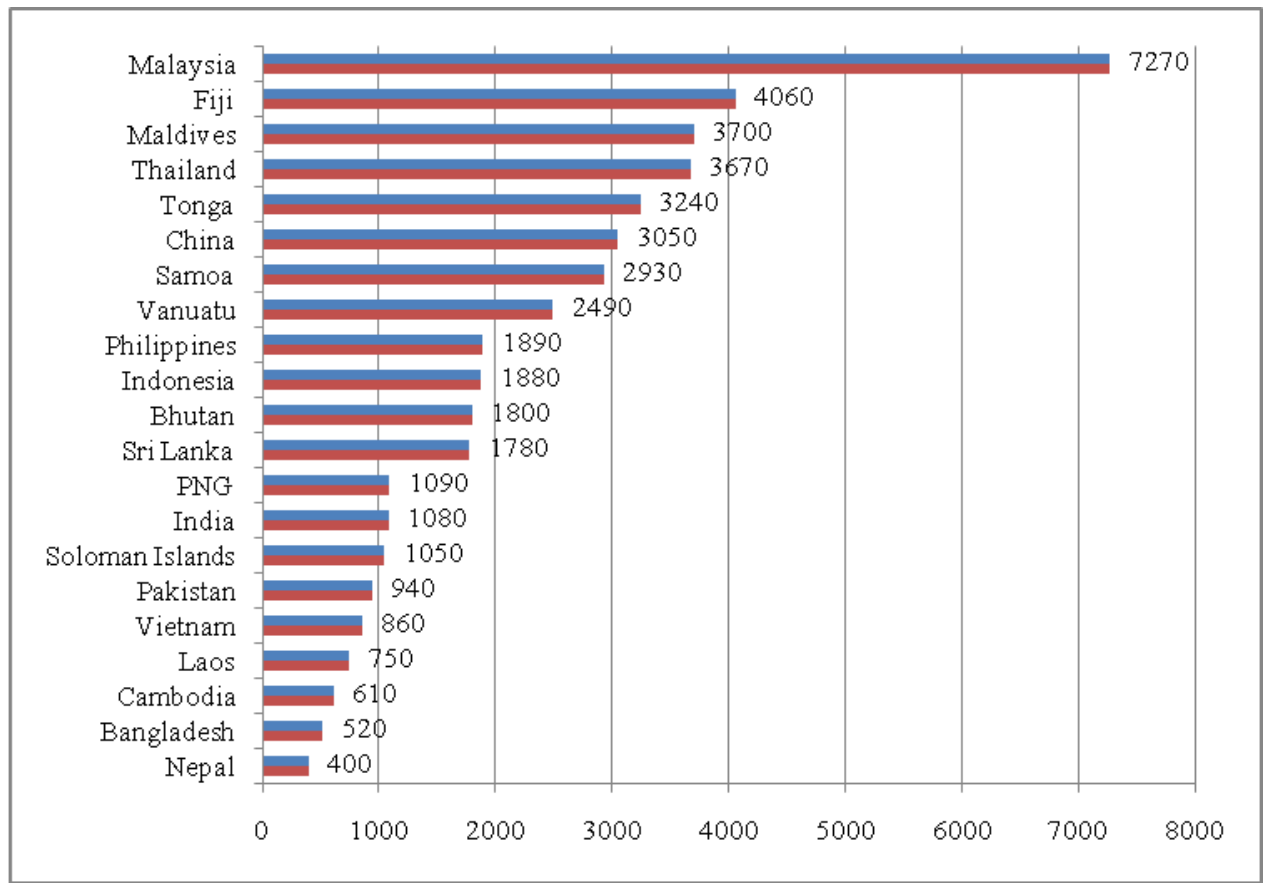

Figure 1: Per capita incomes of Developing Asia (in US\$)

\section{Financial Inclusion in Developing Asia}

Among the key drivers of economic growth, the Australian aid programme focuses on agriculture and rural development; transport, energy and communications; and access to 
finance. Improving access to financial services to the poor and supporting microfinance initiatives in developing countries is one of the key goals of the Australian government and an annual expenditure of $\$ 18$ billion has been set aside on funding bilateral and global microfinance projects for the period 2007-08 - 2012-13. ${ }^{11}$ The government's strategy, in keeping with the guidelines for the funders of microfinance, focuses on achieving: development of the financial institutions through favourable regulatory and policy environment; building capacity of the financial service providers; helping develop innovative financial services models, and improve financial literacy.

Australia is also a member of the G-20 Financial Inclusion Experts Group and in particular is a member of the subgroup - Access through Innovation. ${ }^{12}$ Among the major achievements of Australian initiatives is its support in the launch of new banking services in Fiji using mobile phones. By March 2011 this enabled more than 350,000 people to use banking services including those previously unbanked. In PNG, Australian support to the Microfinance and Employment Project helped in providing new savings accounts for 30,000 people in 2010. The project also linked 35 small village-based providers with formal microfinance institutions. In the Pacific the Australian and New Zealand governments have developed a joint initiative - Reducing the Cost of Remittances to the Pacific which provides web-based information and advice on options and cost of remitting funds to the Pacific. A few other initiatives to improve access to financial services are: support of Capital Aid Fund for the Employment of the Poor in Vietnam; funds of \$9.25 million to CGAP initiated Microfinance Investment and Support Facility for Afghanistan; support to BRAC, the largest NGO in Bangladesh from 2002 to $2008 .^{13}$

Among the major countries of the region India, since the nationalization of banks in 1969 , has traditionally focused on including more and more people, regions, borrowers and sectors within the financial system. Although specific targets set for certain priority sectors aiming to 
reach underserved sectors, small borrowers and less developed regions were always the objective of the Indian banking system, yet a strong cohesive approach targeting the inclusion of the largest possible number of unbanked households, borrowers and all regions was lacking. The recent adoption of the financial inclusion as a strategy of development in the country that aims to widen the depth as well as breadth of the financial system is, therefore, a welcome step in this direction.

Technologically innovative banking and non-banking practices have also been adopted by many countries in the region to improve access to financial services. For instance, in the Philippines the use of mobile phone banking has increased significantly and the number of clients has increased to 4 million people since 2002. Table 1 shows the level of financial inclusion in developing Asia.

\begin{tabular}{|c|c|c|}
\hline Level of Financial Inclusion & \% Financial Inclusion & Countries \\
\hline High & $>50$ & $\begin{array}{c}\text { Thailand, Malaysia, Sri Lanka, Nepal, } \\
\text { Mongolia }\end{array}$ \\
\hline Intermediate & $30-49$ & \begin{tabular}{c} 
India, China, Indonesia, Bangladesh, Vietnam \\
\hline Low
\end{tabular} \\
$\begin{array}{c}\text { Cambodia, Myanmar, Philippines, Papua New } \\
\text { Guinea, Pakistan, Laos, Timor-Leste, } \\
\text { Solomon Islands, Vanuatu, Samoa, Tuvalu, } \\
\text { Kiribati }\end{array}$ \\
\hline
\end{tabular}

Source: Hannig \& Jansen (2010)

Table 1: Level of Financial Inclusion in Asia

\section{Human Capital in Developing Asia}

Human capital, defined as 'direct expenditure on education, training, health and internal migration' was first recognised as a source of economic growth by Shultz. ${ }^{14}$ Becker even titled his book 'Human Capital' and described the forms of human capital as schooling, onthe-job-training, medical care and migration to improve income prospects. ${ }^{15}$ In our study due to data limitations and also as our focus is on education only, we consider education as the key representative of human capital. 
Table 2 displays selected educational indicators as well as per capita incomes in developing Asia. It shows large variation across the countries in terms of absence of schooling (15 years and above) and countries' per capita income. For instance, in Cambodia with a per capita income of US\$610 only 1.3 per cent of the population 15 years and above was without schooling. On the other hand, in Malaysia despite a much higher per capita income (US\$7270) the percentage of population without schooling was 10 per cent.

\begin{tabular}{|c|c|c|c|c|c|}
\hline Countries & $\begin{array}{c}\text { Mean Years of Schooling } \\
(25 \text { years and above }) \\
(2005-10)\end{array}$ & $\begin{array}{l}\text { No Schooling } \\
(2005-10)\end{array}$ & $\begin{array}{c}\text { Expenditure per } \\
\text { primary student }(\% \text { of } \\
\text { GDP per capita) } \\
(2005-10) \\
\end{array}$ & $\begin{array}{l}\text { GDP Per Capita } \\
\text { (2008) (US\$) }\end{array}$ & $\begin{array}{c}\text { Average Annual } \\
\text { Growth Rate of } \\
\text { GDP per capita } \\
(1970-2008) \\
\end{array}$ \\
\hline Bangladesh & 4.5 & 38.3 & 10.3 & 520 & 1.8 \\
\hline Bhutan & - & - & 8.8 & 1800 & 4.5 \\
\hline Cambodia & 5.8 & 1.3 & 6.1 & 610 & 1.9 \\
\hline China & 7.3 & 8.6 & - & 3050 & 7.9 \\
\hline Fiji & 10.9 & 4.2 & 17.4 & 4060 & 1.5 \\
\hline India & 4.2 & 37.6 & 11.1 & 1080 & 3.6 \\
\hline Indonesia & 5.4 & 19.8 & 15.7 & 1880 & 4.3 \\
\hline Laos & 4.4 & 32.7 & 9.0 & 750 & 3.4 \\
\hline Maldives & 4.3 & 25.4 & 21.5 & 3700 & 5.0 \\
\hline Malaysia & 9.2 & 10.0 & 14.6 & 7270 & 4.4 \\
\hline Nepal & 3.0 & 45.2 & 12.7 & 400 & 1.7 \\
\hline Pakistan & 4.7 & 47.7 & - & 940 & 2.4 \\
\hline PNG & 4.1 & 39.7 & - & 1090 & 1.8 \\
\hline Philippines & 8.5 & 4.8 & 11.1 & 1890 & 1.4 \\
\hline Samoa & - & - & 9.8 & 2930 & 1.4 \\
\hline Soloman Islands & 4.5 & - & - & 1050 & 0.7 \\
\hline Sri Lanka & 8.1 & 5.0 & - & 1780 & 3.4 \\
\hline Tonga & 10.3 & 1.1 & 12.1 & 3240 & 2.7 \\
\hline Vanuatu & - & & 16.7 & 2490 & 1.6 \\
\hline Vietnam & 5.2 & 5.7 & 19.7 & 860 & 4.2 \\
\hline Thailand & 6.3 & 12.5 & 17.6 & 3670 & 4.4 \\
\hline Mean & 6.15 & 20.0 & 13.4 & 2145.7 & 3.0 \\
\hline Standard Deviation & 2.3 & 16.8 & 4.4 & 1648.5 & 1.7 \\
\hline $\mathrm{CV} \%$ & 38.1 & 84.2 & 32.6 & 76.8 & 56.3 \\
\hline
\end{tabular}

Source: UNDP (2010); World Bank online database.

Table 2: Selected Educational Indicators in Developing Asia

Figure 2 also shows the relationship between public expenditure on education and per capita income in developing Asia. The expenditure on education was low in countries with low per capita income, yet it can also be seen that even in countries with high per capita income such as Malaysia public spending on education was low. 


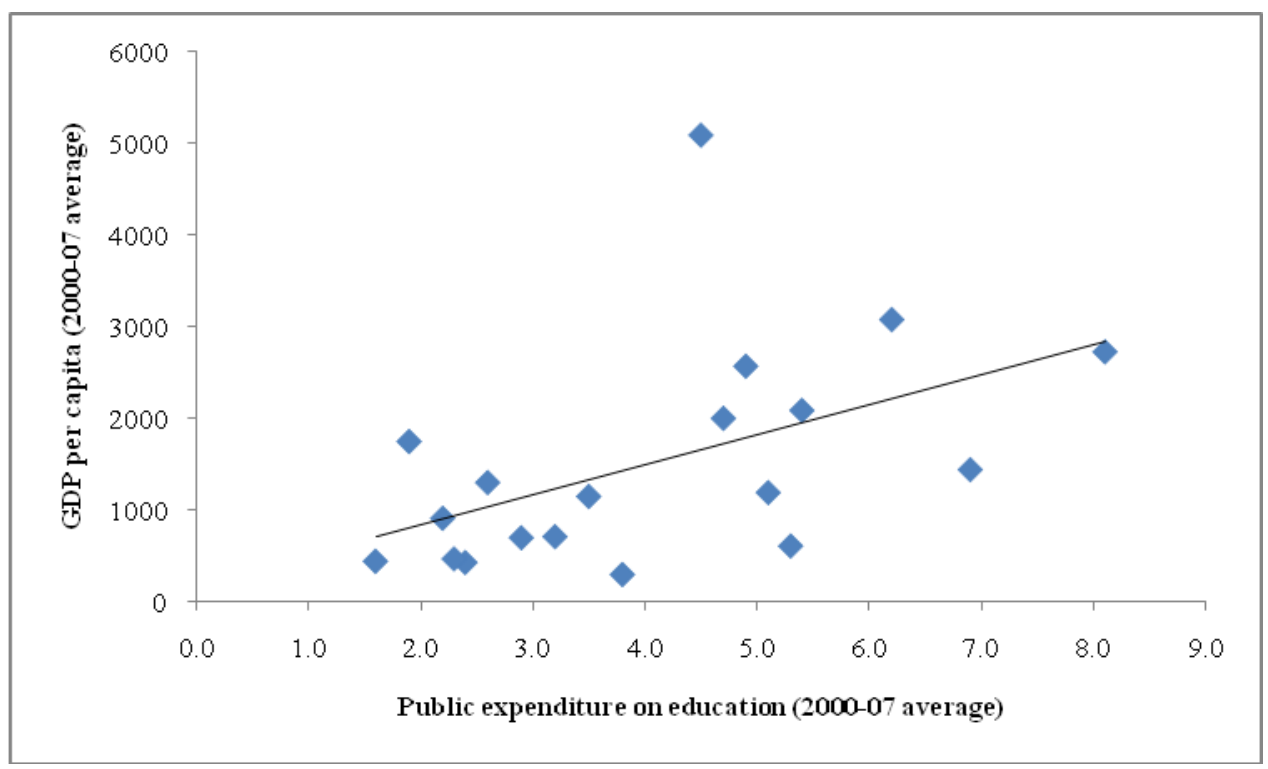

Figure 2: Public expenditure on education and GDP per capita in Developing Asia

\section{Theoretical and empirical relationship between finance and human capital}

Theoretically, financial development is as important as human capital and both together contribute significantly to economic growth. ${ }^{16}$ Physical capital combined with poor human development may produce low growth and poor development outcomes. ${ }^{17}$ Conversely, high human development in the presence of low physical capital may not lead to positive growth outcomes, such as the State of Kerala in India, which though lacking in physical capital scores much higher in almost all aspects of human development and yet its growth numbers have not been encouraging. Lack of growth in Kerala particularly in the pre-nineties is attributed to high trade unionism in the state. High levels of education in the state also stalled the state's growth rate as people with high education shunned jobs below their educational status including the agricultural sector leading to high unemployment and out-migration to other states and even overseas. ${ }^{18}$

Human capital and physical capital both determine growth endogenously and are crucial to economic growth. ${ }^{19}$ Though both are required for long run growth, the accumulation of 
physical capital takes place in the early stages and human capital accumulation follows. ${ }^{20}$ They are determined endogenously as physical capital leads to increase in education level which in turn influences physical stock. ${ }^{21}$ Also tropical climate and land locked regions has no negative effect on physical or human capital. ${ }^{22}$

Are the returns for the poor people through accumulation of these forms of capital low? The interaction of physical and human capital among the poor highlights the need to increase education, as the poor obtain weaker results in physical capital accumulation. ${ }^{23}$ The emphasis on physical capital accumulation alone in the development process could lead to emergence of inequalities, which do accentuate growth, but as the human capital accumulation takes place, the inequalities are reduced. ${ }^{24}$

Chou and Chinn $(2001)^{25}$ examined the relationship between financial development and human capital in generating endogenous growth. They developed a theoretical model where human capital was posited as a key factor in creating financial innovations resulting in financial development which in turn leads to further creation of human capital. Thus financial innovations in their model denote larger stocks of financial products and the financial intermediaries by transforming the savings of households into investment further enable increase in human capital. They suggest that government should play an active role in financial development and also improve productivity and efficiency of financial innovations.

\section{Empirical Studies}

In a panel dataset of 18 Latin American countries covering the period 1965-80 Grier (2002) modelled human and physical capital simultaneously using political stability, type of regime; government spending; income inequality, diversity, trade openness and climate as 
explanatory variables. The study found that human and physical capital are jointly determined endogenously as increases in the stock of physical capital raise education, which in turn influences physical capital. Among other factors the study found climate as negatively related to accumulation of human capital.

Evans et al. (2002) evaluated the contributions of human capital and financial development to economic growth in a panel of 82 countries covering the 21 years period 1972-93. They examined the relationship between human capital, financial development and economic growth using translog production function as a framework. Integrating human capital; monetary factors and labour and physical capital, the results of their study suggested both financial development and human capital contribute equally to economic growth. Also their study suggested that this relationship persists irrespective of the specific indicators adopted for financial development and human capital.

Van de Walle (2003) in the case of Vietnam examined whether returns on irrigation investment are influenced by educational level of the borrowers. The study found that strong relationship exists between irrigation expansion and household education. The study, therefore, argued that measures need to be taken to reduce educational disparities, absence of which will lead to unequal growth in the country.

Seghers et al. $(2009)^{26}$ investigate how entrepreneurs' human and social capital influences their knowledge of finance alternatives and its absence leads to poor information about financial products. Using a survey data of 125 Belgian start-up firms, they showed that entrepreneurs with business education and finance had much more knowledge of financial 
products and that basic education had no effect on the knowledge of financial alternatives. The authors further argued that usually supply side factors gain prominence in the finance literature which suggests that finance does not flow to the small firms and small and poor borrowers due to asymmetric information and moral hazard issues. The factors emerging from low or inadequate human capital which could constrain borrowers' demand are not examined.

In a survey of 297 new small enterprises in Romania, Brown, Earle and Lup (2004) ${ }^{27}$ found that, while access to external credit increases firms' sales and employment, taxes constrain growth. Their findings also suggest that entrepreneurial skills have little effect on growth. Thus they found that the effect of human capital on employment and sales growth is weaker than those of the financial variables.

Cole, Sampson, \& Zia $(2010)^{28}$ explored the determinants of demand for financial services in the emerging markets. The authors conducted household surveys in India and Indonesia and supplemented the survey data with a randomized field experiment among unbanked households in Indonesia to examine the relative importance of financial literacy and prices in determining demand for financial services. Thus, financial literacy programs were offered to half of the surveyed individuals as against a subsidy of $\$ 3$ to $\$ 14$ to the other half of the people to open bank accounts. The results of their experiment showed that financial literacy education had no impact on the opening of bank accounts, although initial levels of education, even though low, did influence the decision to open the bank account. Financial subsidy, however, was a significant incentive in opening the bank accounts and their follow up survey two years later found that people who opened their bank accounts following the 
interventions kept their bank accounts opened even after two years. Education was thus found to be an important factor in influencing financial decisions of people.

Among the studies on access to finance Kumar et al. $(2005)^{29}$ found that education, along with other socio-economic characteristics such as income and wealth, is one of the major determinants of financial access. Their study found that people with higher education used private banks more than the public sector banks and other public payment outlets such as banking agents. Similarly the percentage of population holding bank accounts varied with the educational level.

In a yet another study on the Kenyan financial system, Beck et al. $(2010)^{30}$ found that access to services declines from formal to semi-formal providers in rural areas compared to urban areas; low income people compared to high income and poor or no education as compared to better educated people. The study also noted that only 10 per cent of the population with tertiary education accessed informal finance. They, however, found numeracy is not significantly associated with the use of either formal or informal services.

Nguyen $(2008)^{31}$ established that in Vietnamese households education was positively related to financial development. Household savings was also found to be positively related to education, household size and fixed assets. Other key determinants influencing financial development were social relationship, location, fixed assets, household size, age of household and kin groups.

\section{Methodology and Model specification}

Our plan to explore, in a cross-sectional analysis, the relationship between financial development and human capital in developing Asia is at three levels. First, to find out the current state of financial development and human capital in developing Asia we collect data 
on a range of indicators and develop them into indices. This enables us to group together a large amount of available information about countries' financial and human capital into single series and rank the countries accordingly.

Although studies have used different indicators of financial development, a single indicator such as M3/GDP or M2/GDP may not reflect the actual financial development measured by its outreach, size, depth, stability and access to finance. King \& Levine (1993a) consider four variables: liquid liabilities to GDP; ratio of domestic assets of banks to banks domestic assets plus central bank assets; ratio of private sector credit to total credit and private sector credit to GDP ratio. Creane, Goyal, Mobarak, \& Sab $(2003)^{32}$ provide a comprehensive definition of what is financial development. According to them:

Financial sector development is a multifaceted concept, encompassing not only monetary aggregates and interest rates (or rates of return) but also financial openness, regulation and supervision, technological advances, degree of competition, and institutional capacity such as the strength of creditor rights.

They collected data on 100 quantitative and qualitative variables for the Middle East and North Africa (MENA) region and grouped them into six categories: development of monetary sector and monetary policy; banking sector size, structure and efficiency; quality of banking regulation and supervision; development of non-banking financial sector; financial openness; and institutional environment.

Credit is often taken as an indicator of financial development. Credit, however, cannot be the sole indicator as the financial intermediaries perform several other functions besides providing credit. For example, they accelerate savings rates by offering savings products of different maturities and yields, and allocate these resources to increase investment. They also reduce risks across projects, firms, and industries by risk diversification through which they accelerate technological change and economic growth. By opening bank branches, far and 
wide, banks also develop banking habits (practice of going to the banks, and performing banking transactions) among the population in the early stages of economic development. ${ }^{33}$ In less developed countries where property rights are not well developed, there is a large informal sector, financial systems are not well developed and requirements of collateral exist, credit is often not the most sought after financial product by the people. In these situations banks are very often used as safe custodians and holders of deposits and large sections of the poor population performs simple functions of withdrawing and depositing funds of small denominations.

More recently, World Economic Forum 2010 released its Financial Development Report for the year 2010. It developed financial development index for 57 countries (both developed and developing) on the basis of large number of variables grouped into six pillars- institutional environment; business environment; financial stability; banking financial services; nonbanking financial services; financial markets; and financial access.

Following Creane et al. we build financial development index for developing Asia using indicators that reflect monetary policies; size and depth of the banking system; regulatory practices, financial openness and institutional environment, and rank the countries based on their level of financial development.

In order to investigate where the countries stand with respect to human capital we develop an index, similar to the financial development index, including variables which reflect quantity and quality of human capital. In constructing both indices, the study follows the UNDP methodology in the construction of its Human Development Index. The values 0 or close to 0 imply lowest financial and human capital development and value 1 indicates highest 
development. In the construction of HDI for the year 2010, UNDP adopted a geometric rather than arithmetic mean, as had been done in the earlier years which has resulted in lower index values. ${ }^{34}$

Following UNDP, our educational development index is based on four pillars of human capital - achievements in education (measured by literacy rate 25 years and above; population with secondary education and expected years of schooling); access to education (primary, secondary and tertiary enrolments); efficiency of primary education (drop-out rates and repetition rates) and quality of primary education (trained teachers and pupil teacher ratio) (Appendix 1).

Weights have to be assigned while building the educational development index. Attaching appropriate weights is problematic as they may vary across different levels of education. ${ }^{35}$ Studies also suggest that they should vary with the country's stage of development assuming that in the early stages of economic development, primary education may be more relevant and as development progresses secondary and tertiary education gain in importance. ${ }^{36}$ This, however, does not hold true in the case of India where historically tertiary education has played a much stronger role than primary education. The strong growth noticed after the reforms particularly in the information technology sector is partly attributable to India's traditional emphasis on higher education. Even in 1857-58 there were 3 universities and 27 colleges in the country. ${ }^{37}$ The country is however, still to achieve universal primary education and the gross enrollment ratio is below many other countries.

Furthermore, the Financial Development Index is based on financial development indicator (M2/GDP); banking sector development (non-performing loans; interest rate spread; 
domestic credit to private sector; total value of stocks traded as percentage of GDP; total physical access measured by number of bank branches and ATMs per 100,000 people); Financial Freedom as developed by the Heritage Foundation ${ }^{38}$; Regulation and Supervision (includes bank capital to assets ratio) and institutional environment (measured by credit depth of information index and strength of legal rights index) (Appendix 2).

We further employ PCA to summarise several variables (as discussed above) and to narrow down our choice of variables to significant components. This is also done to reduce the dataset to a more manageable size and to reduce the problem of multicollinearity which can exist particularly among human capital indicators. It also helps in dealing with the problem of overparametrization. ${ }^{39}$

As a last step based on the components arrived at by employing PCA, we regress financial development on human capital indicators using OLS techniques to examine the relationship between financial development and human capital in developing Asia. Our equation runs like this:

$Y i=(b o+b 1 X i 1+b 2 X i 2+b 3 X 3)+\varepsilon i$

where $\boldsymbol{Y}$ is our financial development variable, M2/GDP, $\boldsymbol{b} 1$ is the coefficient of our first education variable, pupil-teacher ratio (Xi1), $b 2$ is the coefficient of the second predictor, mean years of schooling and $b 3$ is the coefficient of third variable - primary enrolment rate. $\boldsymbol{\varepsilon} \boldsymbol{i}$ is the difference between the predicted and observed value of $\mathrm{Y}$ for the $\mathrm{i}^{\text {th }}$ participant. 
In our second model ACCESS (physical access to banks) is our new dependent variable and our equation for this model is:

$$
\text { ACCESS }=(b o+b 1 X i 1+b 2 X i 2+\cdots b 3 X 3+b 4 X 4)+\varepsilon i
$$

where $\boldsymbol{b} \mathbf{1}$ is the coefficient of our first education variable, no schooling $(\boldsymbol{X i 1}), \boldsymbol{b} 2$ is the

coefficient of the second predictor, public expenditure on education; b3 is the coefficient of third variable primary enrolment rate and finally, $b 4$ is the coefficient of our fourth variable expected years of schooling. $\varepsilon i$ is the difference between the predicted and observed value of $\mathrm{Y}$ for the $\mathrm{i}^{\text {th }}$ participant.

To test which model predicts well the nature of relationship between financial development and human capital we also regress financial development index values as our dependent variable on the human development index values. The advantage of using this model over the previous ones is that it is a composite indicator and, therefore, reflects the multidimensionality of financial and educational development.

The study is limited to the years 2005-2010 and data are obtained from World Bank online database, IMF Financial access database, UNDP and Heritage Foundation.

\section{Results}

Table 3 shows ranking of the sample countries in Education Development Index and Financial Development Index. Interestingly, two different sets of trends emerge in the two indices. The countries which have done well in the education development index have fared 
poorly in financial development and the reverse when countries not performing well in educational development have done better in terms of financial development.

Geographically, the top five performers in educational development index are located in Pacific, South Asia and South-East Asia thus showing no clear pattern in terms of geographical location. Nepal, Bangladesh, PNG and Solomon Islands, again no clear geographical locational pattern (two each from South Asia and Pacific), perform poorly both in the educational and financial development.

\begin{tabular}{|c|c|c|c|c|c|}
\hline Country & $\begin{array}{l}\text { Normalised } \\
\text { Education } \\
\text { Development } \\
\text { Index }\end{array}$ & $\begin{array}{c}\text { Ranking in } \\
\text { Education } \\
\text { Development } \\
\text { Index }\end{array}$ & $\begin{array}{l}\text { Normalised } \\
\text { Financial } \\
\text { Development } \\
\text { Index }\end{array}$ & $\begin{array}{l}\text { Ranking in } \\
\text { Financial } \\
\text { Development } \\
\text { Index }\end{array}$ & $\begin{array}{l}\text { Per } \\
\text { capita } \\
\text { Income } \\
2008(\$)\end{array}$ \\
\hline Maldives & 1.000 & 1 & 0.223 & 14 & 3700 \\
\hline Vietnam & 0.957 & 2 & 0.432 & 9 & 860 \\
\hline Philippines & 0.946 & 3 & 0.201 & 15 & 1890 \\
\hline Indonesia & 0.900 & 4 & 0.397 & 10 & 1880 \\
\hline Fiji & 0.870 & 5 & 0.527 & 7 & 4060 \\
\hline Sri Lanka & 0.857 & 6 & 0.299 & 11 & 1780 \\
\hline Samoa & 0.823 & 7 & 0.265 & 13 & 2930 \\
\hline Bhutan & 0.798 & 8 & 0.000 & 21 & 1800 \\
\hline Tonga & 0.795 & 9 & 0.276 & 12 & 3240 \\
\hline Vanuatu & 0.776 & 10 & 0.550 & 5 & 2490 \\
\hline China & 0.764 & 11 & 0.594 & 3 & 3050 \\
\hline Cambodia & 0.756 & 12 & 0.501 & 8 & 610 \\
\hline Malaysia & 0.742 & 13 & 1.000 & 1 & 7270 \\
\hline Laos & 0.716 & 14 & 0.031 & 19 & 750 \\
\hline Thailand & 0.687 & 15 & 0.947 & 2 & 3670 \\
\hline Pakistan & 0.612 & 16 & 0.572 & 4 & 940 \\
\hline India & 0.605 & 17 & 0.539 & 6 & 1080 \\
\hline Nepal & 0.563 & 18 & 0.124 & 18 & 400 \\
\hline Bangladesh & 0.484 & 19 & 0.180 & 16 & 520 \\
\hline Soloman Islands & 0.303 & 20 & 0.031 & 20 & 1050 \\
\hline PNG & 0.000 & 21 & 0.152 & 17 & 1090 \\
\hline
\end{tabular}

Source: Author's calculations; World Bank Online database.

Table 3: Ranking of Countries in Education Development Index and Financial Development Index

Figure 3 displays graphically ranking of the developing Asian countries in educational and financial development index. 


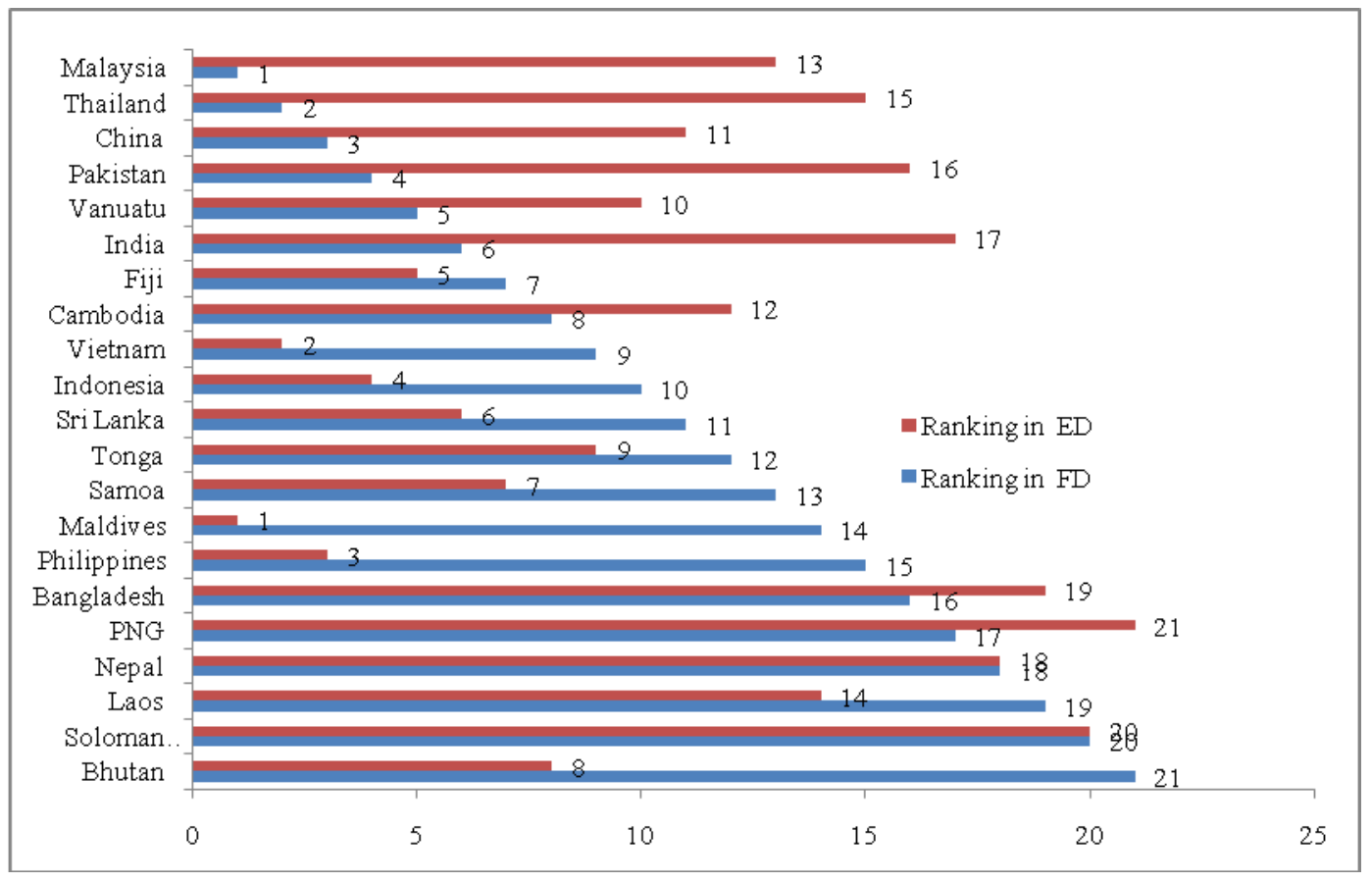

Figure 3: Ranking of Countries in Financial Development Index and Education Development Index

To shortlist the human capital variables and to find out the underlying factors we also performed PCA on seven education variables with varimax rotation. The Kaiser-Meyer-Olkin measure of sampling adequacy worked out to 0.65 . Bartlett's test of sphericity $\chi^{2}(21)=$ $34.735, p<.05$ indicated that correlations were enough for conducting PCA. ${ }^{40}$ An initial analysis was run to obtain eigenvalues for each component in the data. Three components had eigenvalues over Kaiser's criterion of 1 and in combination explained 82.9 per cent of the variance. The scree plot, however, lists one factor and starts taking an elbow shape after the first factor. The three factors finally retained in our analysis were no schooling, mean years of schooling, expected years of schooling, repetition rate (Factor 1); expenditure on education and teacher: pupil ratio (Factor 2); and primary enrolment (Factor 3). Table 4 below shows the rotated component matrix using the extraction method of PCA. 
Rotated Component Matrix

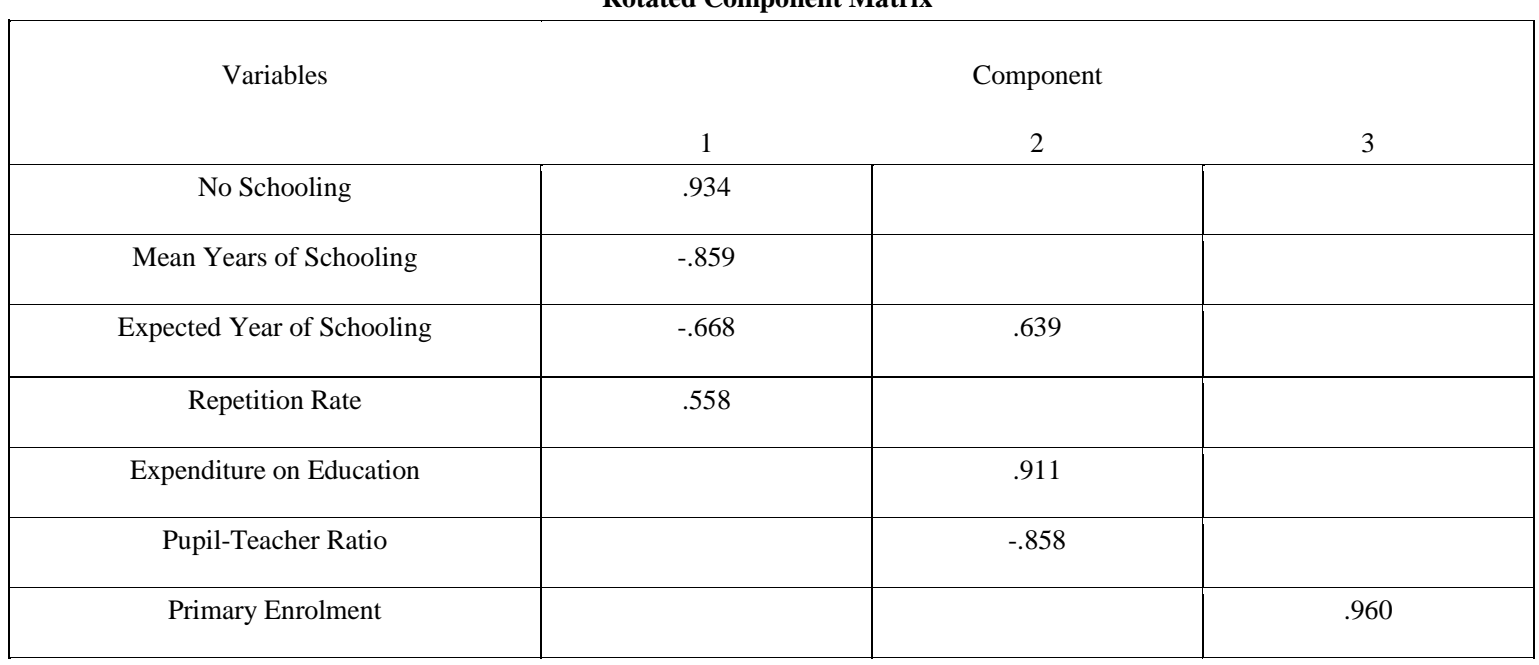

Extraction Method: PCA.

Rotation Method: Varimax with Kaiser Normalization.

Table 4: Summary of Exploratory Factor Analysis

Similar to our exercise for human capital, we also performed PCA on financial variables with varimax rotation. The Kaiser-Meyer-Olkin measure of sampling adequacy worked out to 0.55. Bartlett's test of sphericity $\chi^{2}(28)=49.913, p<.01$ indicated that correlations were enough for conducting PCA. An initial analysis was run to obtain eigenvalues for each component in the data. Two components had eigenvalues over Kaiser's criterion of 1 and in combination explained 72.7 per cent of the variance. The scree plot lists three factors and takes an elbow shape after the third factor. We, therefore, retained only two factors in the analysis. These were M2/GDP; interest rate spread; domestic credit; stocks traded; legal rights (Factor 1) and physical access to banks (including ATMs); financial freedom and credit depth of information index (Factor 2). Table 5 shows the rotated component matrix using the extraction method of PCA. 


\begin{tabular}{|c|c|c|}
\hline M2/GDP & .898 & \\
\hline Interest Rate Spread & -.866 & .526 \\
\hline Domestic Credit & .768 & \\
\hline Value of Stocks Traded & .729 & .918 \\
\hline Legal Rights & .589 & .886 \\
\hline Physical Access to Banks & & .824 \\
\hline Financial Freedom & & \\
\hline Credit Depth of Information & & \\
\hline
\end{tabular}

Extraction Method: PCA. Rotation Method: Varimax with Kaiser Normalization.

Table 5: Summary of Exploratory Factor Analysis

Finally, we regressed financial development indicator M2/GDP on the human capital variables using OLS method (linear form) covering the period 2005-2010. Of seven variables extracted by the PCA on human capital indicators we retain only three based on meaningful results. The results of our exercise in Column 2 show that most of the education variables are not significant (Table 6). The relationship between pupil-teacher ratio (indicator of quality of education) and financial development was significantly negative suggesting that countries with higher ratio of students per teacher can also be expected to have lower financial development. The $\mathrm{R}_{2}$ value between finance and human capital indicators, on the whole, was less than 0.5 indicating a weak relationship between the two. To test for the robustness, we also performed Skewness kurtosis test to check the normality of our dataset and regression was corrected for heteroscadacity. All the independent variables were found to be normally distributed.

\begin{tabular}{|c|c|}
\hline Variables & Coefficients \\
\hline Constant & 224.814 \\
& $(3.77)$ \\
\hline Pupil-Teacher ratio & $-1.610^{* *}$ \\
& $(-2.75)$ \\
\hline Mean Year of Schooling & -1.186 \\
& $(-0.37)$ \\
\hline Primary enrolment rate & -1.106 \\
& $(-2.04)$ \\
\hline Adjusted R & 0.4032 \\
\hline Number of observations & 15 \\
\hline
\end{tabular}

Figures within parenthesis are $P$ values. ** Significant at $5 \%$.

Table 6: Financial Development and Human Capital in Developing Asia: Dependent Variable M2/GDP 
We also examined the relationship between access to banks and human capital in developing Asia. Column 1 in Table 7 shows the variables retained on human capital. Column 2 shows the coefficients obtained and except expected year of schooling, rest all others were subdued. Expected years of schooling, which measures the number of years of schooling that a child of school entrance age can expect to receive based on the prevailing patterns of age-specific enrolment rates ${ }^{41}$, was found to be significantly positively related to physical access to banks suggesting that in countries with higher schooling expectations, physical access to banks also tends to be better.

\begin{tabular}{|c|c|}
\hline Variables & Coefficients \\
\hline Constant & $27.131^{* *}$ \\
& $0.64)$ \\
\hline No Schooling & 0.535 \\
& $(1.31)$ \\
\hline Public expenditure on education & -0.999 \\
& $(-0.29)$ \\
\hline Primary enrolment rate & -0.731 \\
& $(-1.67)$ \\
\hline Expected year of schooling & $11.059^{* *}$ \\
& $(2.67)$ \\
\hline Adjusted R & 0.6121 \\
\hline Number of observations & 15 \\
\hline
\end{tabular}

Table 7: Financial Development and Human Capital in Developing Asia: Dependent Variable: Total Physical Access to Banks

Even though our regression results did not confirm a strong relationship between financial development and the medley of human capital indicators, we checked for the relationship again between the two, but this time we dropped all the human capital indicators included in the above regression exercises and settled for mean years of schooling from Barro Lee database $(2010)^{42}$ to represent human capital. Among financial development indicators we retained only physical access to banks (including ATMs) per 100,000 people and dropped M2/GDP. This data was obtained from the IMF Financial Access Database. To obtain meaningful results and also to improve our dataset we also increased our number of observations and widened our coverage to total 46 developed and few other developing countries (including the sample countries). 
A Pearson product-moment correlation coefficient two tailed test was computed by us to assess the relationship between physical access to banks (banks and ATMs included) and mean years of schooling in selected developed and developing countries. Our results showed a strong positive statistically significant relationship between the two variables $\mathrm{r}(46)=.718, p$ $<.01$ (two tailed). In other words, physical access to banks tends to be higher in countries with higher mean years of schooling. This exercise even for our sample countries (data on both indicators was available for only for 14) yields strong positive results and the correlation turns out to be .60 . However, we may add here that this is only associational relationship between the two and may not indicate causality. Figure 4 shows graphically the relationship between mean years of schooling and physical access to banks.

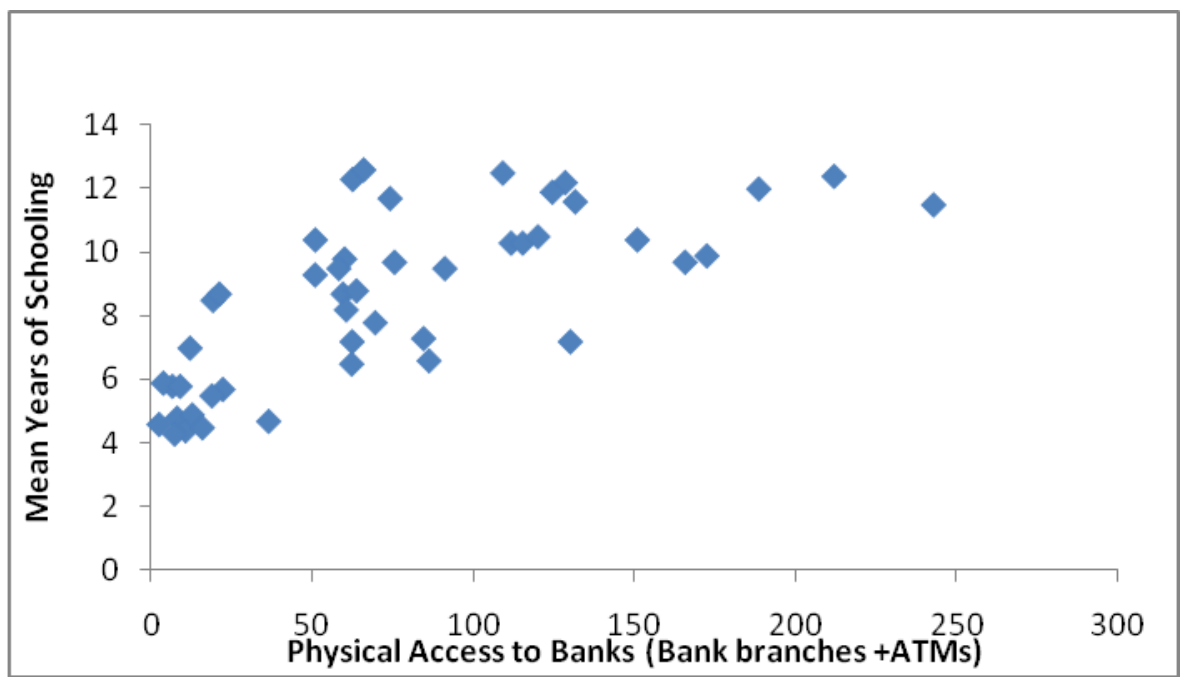

Figure 4: Physical Access to Banks and Mean Years of Schooling in selected developed and developing countries

In our third model, we regress our composite indices- financial development index values as the dependent variable and education development index. The results are shown in Table 8 . Column 2 suggests a weak relationship between the two and the results were not statistically significant. 


\begin{tabular}{|c|c|}
\hline Education Development index & 0.174 \\
& $(0.94)$ \\
\hline Constant & 0.969 \\
& $(2.63)$ \\
\hline Adjusted $\mathrm{R}^{2}$ & -0.0061 \\
\hline Number of observation & 21 \\
\hline
\end{tabular}

Table 8: Relationship between Financial Development Index and Education Development Index: Dependent variable: Financial Development index

A Pearson product-moment correlation coefficient two tailed test computed by us to test the relationship between financial development and education development once again showed a weak relationship between the two variables $r(21)=.210$, (two tailed).

\section{Conclusion}

Financial inclusion has become an important policy goal in developing countries in recent years. The literature on financial inclusion is, however, supply focused and presumes that focus on supply of financial services alone would resolve the issue of financial inclusion. Like some other developed countries, Australia aims under its aid programme to improve access to financial services in the developing countries, and has identified a set of policy outcomes it wishes to achieve, in consonance with the international guidelines on microfinance. In this study, using a three-step detailed methodological approach we examined the relationship between financial development and human capital in developing Asia. Our sample of countries based on the IMF classification is a mixed group with countries at different stages of development, yet in all of them measures are being taken to improve financial inclusion. Also Australia is supporting financial inclusion efforts in many of these countries.

The results of our study showed that countries rank differently in the financial development index and education development index. Thus, countries which rank high in education 
perform poorly in financial development. Of the three regression models run in our study, the results suggest that pupil-teacher ratio and financial development are related negatively suggesting that in countries with low financial development, the quality of education is also very often poor. The strong positive relationship between expected years of schooling (expected years of schooling is based on the current enrolment ratios) and physical access to banks suggest that to improve financial inclusion, measures on improving educational variables also need to be taken contemporaneously.

Further, when we retain only access to banks among financial indicators and mean years of schooling as our human capital indicator our results showed a strong positive statistically significant relationship between the two variables. We may caution here that these results are only associational in nature. Yet they do highlight the importance of increasing bank branching network and thus increasing access to finance and also suggest improving educational outcomes for sustained financial development.

\section{Notes:}

Earlier versions of this paper were presented in the Global Accounting, Finance and Economics Conference, Monash University, Melbourne, Australia and in the Research Seminar Series of Griffith Asia Institute, Griffith University. Comments received from the participants are gratefully acknowledged. I also wish to thank Colin Mackerras, Shyama Ratnasiri and Athula Naranpanawa for their useful comments on the paper. Further, I wish to thank Pradeepa Koralegedara for statistical help.

${ }^{1}$ CFI. Financial Inclusion: What's the Vision? Retrieved June 29, 2011, from http://www.centerfor financial inclusion.org/ Document.Doc?id=778

${ }^{2}$ D Collins, J Morduch, S Rutherford \& O Ruthven, Portfolios of the Poor: How the World's Poor Live on \$2 a Day. Princeton and Oxfordshire: Princeton University Press, 2009.

${ }^{3}$ AusAID, Financial Services for the Poor: A Strategy for the Australian Aid Program 2010-15. Canberra: AusAID, Commonwealth of Australia, 2010.

${ }^{4}$ J Strauss \& D Thomas "Human Resources: Empirical Modeling of Household and Family Decisions," in J Behrman and T N Srinivasan (eds.), Handbook of Development Economics, Vol. 3, Amsterdam: North-Holland, 1995.

${ }^{5}$ RG King \& R Levine 'Finance, entrepreneurship and growth' Journal of Monetary Economics, 32(3): 513542, 1993a; RG King \& R Levine, Finance and Growth: Schumpeter might be right, Quarterly Journal of Economics, 108(3), 717-738,1993b; A Demirguc-Kunt \& R Levine, Finance, Financial Sector Policies, and Long-Run Growth. Washington DC, World Bank: 1-82, 2008; R Levine, 'Financial Development and Economic Growth: Views and Agenda', Journal of Economic Literature 35(2): 688-726, 1997; J Greenwood \& B Jovanovic, 'Financial development, growth, and the distribution of income', Journal of Political Economy 
98(5): 1076-1108, 1990; V Bencivenga \& BD Smith, 'Financial Intermediation and economic growth' Review of Economic Studies, 58(194), 195-209, 1991. Some of the older literature which discussed the role of finance in development is JG Gurley \& ES Shaw 'Financial Aspects of Economic Development', American Economic Review 45(4): 515-538,1955; A Gerschenkron, Economic backwardness in historical perspective- A book of essays, Cambridge, Harvard University Press, 1962; HT Patrick, 'Financial Development and Economic Growth in Underdeveloped Countries', Economic Development and Cultural Change 14(2): 174-189, 1966; R W Goldsmith, Financial Structure and Development, New Haven, Yale University Press, 1969.

${ }^{6}$ JD Gregorio \& PE Guidotti , 'Financial Development and Economic Growth', World Development 23(3): 433448, 1995.

${ }^{7}$ Levine, p688.

${ }^{8}$ D Porteous, Key Issues in Design and Implementation of Surveys on Financial Inclusion. Presented at the Alliance for Financial Inclusion Global Policy Forum. Nairobi, September 15, www. Afi-global.net/ downloads/ GPF_David_Porteous.pdf, 2009.

${ }^{9}$ A Hannig \& S Jansen, Financial Inclusion and Financial Stability: Current Policy Issues (ADBI

Working Paper Series No. 259),Tokyo, Japan: Asian Development Bank Institute, 2010.

${ }^{10} \mathrm{IMF}$, World Economic Outlook (WEO): Tensions from the Two-Speed Recovery: Unemployment,

Commodities, and Capital Flows, Washington DC: International Monetary Fund, 2011. IMF divides the countries into two broad groups- Advanced economies (34 countries) and Emerging and developing economies (150 countries). Emerging and developing economies are further sub divided into six regional subgroups. These are central and eastern Europe; Commonwealth of Independent States; developing Asia; Latin America and the Caribbean; Middle East and North Africa; and Sub-Saharan Africa.

${ }^{11}$ Australian Treasury, Budget, Australia's International Development Assistance Program 2011-12: An Effective Aid Plan for Australia: Reducing Poverty, Saving Lives and Advancing Australia's National Interests, Statement by the Hon Kevin Rudd, MP, Minister for Foreign Affairs. Canberra: Australia Treasury, Government of Australia, 2011.

$12 \mathrm{~J}$ Rosenberg, The G-20 eyes financial inclusion using mobile phones, other ICTs. Retrieved June 20, 2011, from http://technology.cgap.org/2010/03/09/the-g-20-eyes-financial-inclusion-using-mobile-phonesother-icts/, 2010

13 AusAID.

${ }^{14} \mathrm{~T}$ W Shultz, 'Investment in Human Capital', American Economic Review, 51(1): -17, 1961.

${ }^{15}$ G Becker, Human Capital, A Theoretical and Empirical Analysis with Special Reference to Education. Chicago, The University of Chicago Press, $3^{\text {rd }}$ edt, 1993.

${ }^{16}$ A D Evans, CJ Green \& V Murinde, Human Capital and Financial Development in Economic

Growth: New Evidence Using the Translog Production Function, International Journal of Financial Economics, 7, 123-140, 2002.

${ }^{17} \mathrm{~S}$ Bergheim, Human Capital is the key to growth: Success stories and the policies for 2020, Frankfurt, Germany: Deutsche Bank Research, 2005.

${ }^{18}$ N Pani \& K Jafar, 'Mass Education-led Growth and Non-agrarian Villages: Long-term Results of the Kerala Model', Oxford Development Studies 38(1): 25-42, 2010.

${ }^{19} \mathrm{~J}$ Caballe \& S Santos, On Endogenous Growth with Human and Physical Capital. Journal of Political Economy, 101(6), 1042-1067, 1993.

${ }^{20} \mathrm{~J}$ Graca, S Jafarey, et al. 'Interaction of Human and Physical Capital in a Model of Endogenous Growth' Economics of Planning 28: 93-118, 1995.

${ }^{21}$ R Grier, 'On the Interaction of Human and Physical Capital in Latin America', Economic Development and Cultural Change, 50(4): 891-913, 2002.

${ }^{22}$ R Grier, 'The Interaction of Physical and Human Capital Accumulation: Evidence from Sub-Saharan Africa', Kyklos , 58(2): 195-211, 2005.

${ }^{23}$ D Van de Walle, 'Are Returns to Investment Lower for the Poor? Human and Physical Capital Interactions in Rural Vietnam', Review of Development Economics, 7(4): 636-653, 2003.

${ }^{24} \mathrm{O}$ Galor \& O Moav, 'From Physical to Human Capital Accumulation: Inequality and the Process of Development', Review of Economic Studies, 70: 1001-1026, 2004.

${ }^{25}$ YK Chou \& M Chinn, Human Capital, Financial Innovations and Growth: A Theoretical Approach. Research Paper Series, No 826, Melbourne, Department of Economics, University of Melbourne, 2001.

${ }^{26}$ A Seghers, S Manigart \& T Vanacker, The impact of human and social capital on entrepreneurs' knowledge of finance alternatives, No. 2009/617, Gent: University of Gent, 2009.

${ }^{27}$ JD Brown, JS Earle \& D Lup, What makes small firms grow? Finance, human capital, Technical assistance, and the business environment in Romania, Upjohn Institute Staff Working Paper No. 03-94, 2004. 
${ }^{28}$ S Cole, T Sampson \& B Zia, Prices or Knowledge? What Drives Demand for Financial Services in Emerging Markets? Retrieved June 28, 2011, from http://www.rhsmith.umd.edu/finance/ pdfs_docs/ Seminar Fall2010/ZiaBilal.pdf, 2010.

${ }^{29}$ A Kumar, T Beck, C Campos \& S Chattopadhyay, Assessing Financial Accessin Brazil, World Bank Working Paper No. 50, Washington DC: World Bank, 2005.

${ }^{30}$ T Beck, R Cull, M Fuchs, J Getenga,., P Gatere, J Randa, et al. Banking Sector Stability, Efficiency, and Outreach in Kenya, Policy Research Working Paper No. WPS5442, Washington DC: World Bank, 2010.

${ }^{31} \mathrm{D}$ P Nguyen, The Impacts of Financial Development on Economic Activities in Vietnam, Unpublished Doctoral Thesis, University of Adelaide, Adelaide, Australia, 2008.

${ }^{32}$ S Creane, R Goyal, A Mobarak \& R Sab, Financial Development in the Middle East and North Africa. Finance and Development, 40(1), 26-29, 2003.

${ }^{33}$ RC Porter, 'The Promotion of the Banking Habit and Economic Development', Journal of Development Studies, 2(4), 346-366, 1966.

${ }^{34}$ UNDP, Human Development Report 2010: The Real Wealth of Nations: Pathways to Human Development20th Anniversary Edition New York: United Nations Development Programme, 2010.

${ }^{35}$ P Richardson, Globalisation and Linkages: Macrostructiural Challenges and Opportunities, OECD Economics Studies, No 28, Organisation for Economic Cooperation \& Development, Paris; Revoredo, C.L. \& Morisset , J.P. (1999). Savings and education: a life-cycle model applied to a panel of 74 countries, Policy Research Working Paper No 1504, World Bank, Washington DC, 1997.

${ }^{36}$ A Bayhaqi, Education and macroeconomic performance in Indonesia: a Comparison with other ASEAN economies, EADN Working Papers No 8, East Asian Development Network, Bangkok, 2001.

${ }^{37}$ A Panagariya, India: The Emerging Giant. New York: Oxford University Press, 2008.

${ }^{38}$ Financial freedom constructed by Heritage Foundation measures banking efficiency and independence from government control and interference. The factors taken into account are extent of government regulation of financial services; state ownership of banks; extent of financial and capital market development; government influence in credit allocation; and openness to foreign competition. The scores are from 0-100 where 100 indicates negligible government influence and 0 indicates repressive financial system.

${ }^{39}$ J B Ang, Finance and Inequality: The Case of India. Southern Economic Journal, 76(3), 738-761, 2010.

${ }^{40}$ A Field, Discovering statistics using SPSS : (and sex, drugs and rock'n'roll) (3rd ed.). London: Sage Publications, 2009.

${ }^{41}$ UNDP (2010).

${ }^{42}$ R J Barro \& J-W Lee, A New Data Set of Educational Attainment in the World, 1950-2010 (NBER

Working Paper No. 15902): The National Bureau of Economic Research, 2010. 


\section{Appendix 1}

Components of Education Development Index

\begin{tabular}{|c|c|c|c|c|c|c|}
\hline Country & $\begin{array}{l}\text { Achievements } \\
\text { in Education }\end{array}$ & $\begin{array}{l}\text { Access to } \\
\text { Education }\end{array}$ & $\begin{array}{l}\text { Efficiency } \\
\text { of Primary } \\
\text { Education }\end{array}$ & $\begin{array}{l}\text { Quality of } \\
\text { Primary } \\
\text { Education }\end{array}$ & Index & $\begin{array}{l}\text { Normalised } \\
\text { Index }\end{array}$ \\
\hline Bangladesh & 0.283 & 0.263 & 0.487 & 0.341 & 1.37 & 0.48 \\
\hline Bhutan & 0.402 & 0.365 & 0.838 & 0.513 & 2.12 & 0.80 \\
\hline Cambodia & 0.553 & 0.346 & 0.514 & 0.608 & 2.02 & 0.76 \\
\hline China & 0.593 & 0.396 & 0.995 & 0.055 & 2.04 & 0.76 \\
\hline Fiji & 0.458 & 0.354 & 0.939 & 0.538 & 2.29 & 0.87 \\
\hline India & 0.374 & 0.390 & 0.709 & 0.189 & 1.66 & 0.61 \\
\hline Indonesia & 0.566 & 0.477 & 0.818 & 0.499 & 2.36 & 0.90 \\
\hline Laos & 0.504 & 0.354 & 0.520 & 0.545 & 1.92 & 0.72 \\
\hline Maldives & 0.775 & 0.617 & 0.878 & 0.327 & 2.60 & 1.00 \\
\hline Malaysia & 0.654 & 0.391 & 0.890 & 0.050 & 1.99 & 0.74 \\
\hline Nepal & 0.305 & 0.382 & 0.483 & 0.392 & 1.56 & 0.56 \\
\hline Pakistan & 0.251 & 0.195 & 0.722 & 0.509 & 1.68 & 0.61 \\
\hline PNG & 0.224 & 0.003 & - & - & 0.23 & 0.00 \\
\hline Philippines & 0.654 & 0.464 & 0.777 & 0.574 & 2.47 & 0.95 \\
\hline Samoa & 0.769 & 0.365 & 0.955 & 0.088 & 2.18 & 0.82 \\
\hline $\begin{array}{l}\text { Soloman } \\
\text { Islands }\end{array}$ & 0.523 & 0.422 & - & - & 0.95 & 0.30 \\
\hline Sri Lanka & 0.617 & 0.585 & 0.976 & 0.080 & 2.26 & 0.86 \\
\hline Tonga & 0.811 & 0.439 & 0.861 & & 2.11 & 0.80 \\
\hline Vanuatu & 0.599 & 0.309 & 0.614 & 0.544 & 2.07 & 0.78 \\
\hline Vietnam & 0.677 & 0.363 & 0.931 & 0.523 & 2.49 & 0.96 \\
\hline Thailand & 0.573 & 0.473 & 0.735 & 0.072 & 1.86 & 0.69 \\
\hline
\end{tabular}




\section{Appendix 2}

Components of Financial Development Index

\begin{tabular}{|c|c|c|c|c|c|c|c|}
\hline Country & $\begin{array}{l}\text { Monetary } \\
\text { Policy }\end{array}$ & $\begin{array}{l}\text { Banking } \\
\text { Sector }\end{array}$ & $\begin{array}{l}\text { Financial } \\
\text { Freedom }\end{array}$ & $\begin{array}{c}\text { Regulation } \\
\& \\
\text { Supervision }\end{array}$ & $\begin{array}{c}\text { Institutional } \\
\text { Environment }\end{array}$ & Index & $\begin{array}{c}\text { Normali } \\
\text { sed } \\
\text { Index }\end{array}$ \\
\hline Bangladesh & 0.18 & 0.18 & 0.13 & 0.07 & 0.43 & 0.98 & 0.18 \\
\hline Bhutan & 0.14 & 0.18 & 0.25 & & 0.11 & 0.68 & 0.00 \\
\hline Cambodia & 0.07 & 0.16 & 0.50 & & 0.78 & 1.51 & 0.50 \\
\hline China & 0.49 & 0.22 & 0.25 & 0.13 & 0.58 & 1.67 & 0.59 \\
\hline Fiji & 0.19 & 0.11 & 0.63 & & 0.63 & 1.56 & 0.53 \\
\hline India & 0.21 & 0.14 & 0.38 & 0.16 & 0.69 & 1.58 & 0.54 \\
\hline Indonesia & 0.12 & 0.11 & 0.38 & 0.33 & 0.41 & 1.34 & 0.40 \\
\hline Laos & 0.05 & 0.22 & 0.13 & & 0.33 & 0.73 & 0.03 \\
\hline Maldives & 0.22 & 0.25 & 0.25 & & 0.33 & 1.05 & 0.22 \\
\hline Malaysia & 0.40 & 0.23 & 0.50 & 0.21 & 1.00 & 2.34 & 1.00 \\
\hline Nepal & 0.18 & 0.08 & 0.25 & & 0.38 & 0.89 & 0.12 \\
\hline Pakistan & 0.15 & 0.17 & 0.38 & 0.37 & 0.58 & 1.63 & 0.57 \\
\hline PNG & 0.13 & 0.11 & 0.25 & & 0.44 & 0.94 & 0.15 \\
\hline Philippines & 0.17 & 0.11 & & 0.43 & 0.31 & 1.02 & 0.20 \\
\hline Samoa & 0.14 & 0.18 & 0.25 & & 0.56 & 1.12 & 0.26 \\
\hline $\begin{array}{l}\text { Soloman } \\
\text { Islands }\end{array}$ & 0.08 & 0.18 & 0.25 & & 0.22 & 0.73 & 0.03 \\
\hline Sri Lanka & 0.11 & 0.13 & 0.38 & & 0.57 & 1.18 & 0.30 \\
\hline Tonga & 0.14 & 0.21 & 0.13 & & 0.67 & 1.14 & 0.28 \\
\hline Vanuatu & 0.30 & 0.14 & 0.38 & & 0.78 & 1.59 & 0.55 \\
\hline Vietnam & 0.31 & 0.15 & 0.25 & & 0.69 & 1.40 & 0.43 \\
\hline Thailand & 0.34 & 0.28 & 0.75 & 0.32 & 0.57 & 2.25 & 0.95 \\
\hline
\end{tabular}

